\title{
Some historical aspects of plant cytogenetics in Argentina and Uruguay
}

\author{
Juan H. Hunziker
}

Departamento de Ciencias Biológicas, Instituto de Botánica Darwinion, Facultad de Ciencias Exactas y Naturales, Ciudad Universitaria (1428), C. C. 22, San Isidro (1642),Buenos Aires, Argentina.E-mail: jhunziker@darwin.edu.ar

\section{Abstract}

A brief account is given of the origin and development of plant cytogenetics in Argentina and Uruguay, along with some of the factors that hampered the development of this area.

It is beyond my ability to give a complete historical picture of the development of plant cytogenetics in Latin America, therefore, I will concentrate on some aspects of its development in Argentina and Uruguay.

In the Rio de la Plata area some plant cytogeneticists have been autodidacts of great merit, while others had teachers in our countries, the USA or Europe. The development of cytogenetics in this area has been dealt with previously (Hunziker, 1976, 1980, 1990, 1994; Hunziker and Sáez, 1976; Mazoti and Hunziker, 1976), and in Hunziker and Sáez (1976) a detailed bibliography is given for Argentina covering the period 1923-1972.

In Figure 1 I have tried to depict the "genealogy" of the scientists involved in plant cytogenetics and to represent the influence of their diverse teachers and the interactions between them (indicated by the arrows). I apologize for the inevitable omissions and mistakes and for the partial treatment of the subject, and, although the different groups of cytogeneticists are indicated, it is impossible to deal in detail with their accomplishments in an article of this size (more details about some of these scientists can be found in Hunziker and Saéz, 1976).

The beginnings of cytogenetics in Latin America can be traced to La Plata and Buenos Aires in the first quarter of this century. At the University of La Plata the Zoology Professor Dr. Miguel Fernández, discoverer in 1909 of polyembryony in the "mulita" (Dasypus hybrida), had two distinguished students, Francisco A. Saéz and Salomón Horovitz. Both were the initiators of plant cytology and began using Belling's acetocarmin technique in 1925 and 1926, respectively. Saéz formed groups at La Plata and Buenos Aires, while Horovitz formed groups at Buenos Aires, La Plata and Llavallol (Instituto Fitotécnico de Sta. “...history, emulator of time, depository of actions, witness of the past, example and announcement of the present, warning about the future." MIGUEL DE CERVANTES SAAVEDRA El Ingenioso Hidalgo Don Quijote de la Mancha, Part 1, Chapt. 9.

Catalina) (Figure 1), where in the thirties, he trained several geneticists and cytogeneticists. Among those trained by Horovitz were Benno Schnack and Guillermo Covas, who collaborated in the forties and worked together in Mendoza on several problems on the cytogenetics of interspecific hybrids of Verbenaceae and Hordeum, and made chromosome counts on over two hundred species of the vascular flora of Argentina. Later, in Castelar and La Plata, they trained several plant cytologists, among them Otto Solbrig, who some years later became Professor of Botany at Harvard University.

In 1946 the book General Cytology by E. De Robertis, W.W. Nowinski and F.A. Saéz was published, a work which helped to develop interest in cytological problems among the younger generation and which was eventually translated into eight foreign languages.

At Buenos Aires University, Lucien Hauman, an outstanding botany teacher, born and trained in Belgium, had an enthusiastic student, Lorenzo R. Parodi, who later became a grass taxonomist and Professor of Botany at the universities of Buenos Aires and La Plata. Parodi had a special gift for attracting students to botanical research, whom he first trained as taxonomists but later encouraged some of them to study cytogenetics in Berkeley, California under the tuition of Professor George L. Stebbins, a world authority in plant evolution. Despite the fact that at that time there was no regular state system for studying abroad, Juan I. Valencia (1946), Guillermo Covas (1948), and Juan H. Hunziker $(1951,1957,1958)$ were trained by Stebbins and worked on several projects dealing with the cytogenetics of grass hybrids and biosystematics. Two other former students of Parodi, Armando T. Hunziker (Córdoba) and A. Krapovickas (Corrientes), developed botanical centers which became important for plant cytogenetics (Figure 1). In the mid forties J.I. Valencia worked at Berkeley under Professor G.L. Stebbins on the cytogenetics of interspecific hybrids in the Triticeae, and later he also dealt with the cytotaxonomy of Streptochaeta and Piptochaetium (Gramineae). In the late fifties Valencia organized a human 

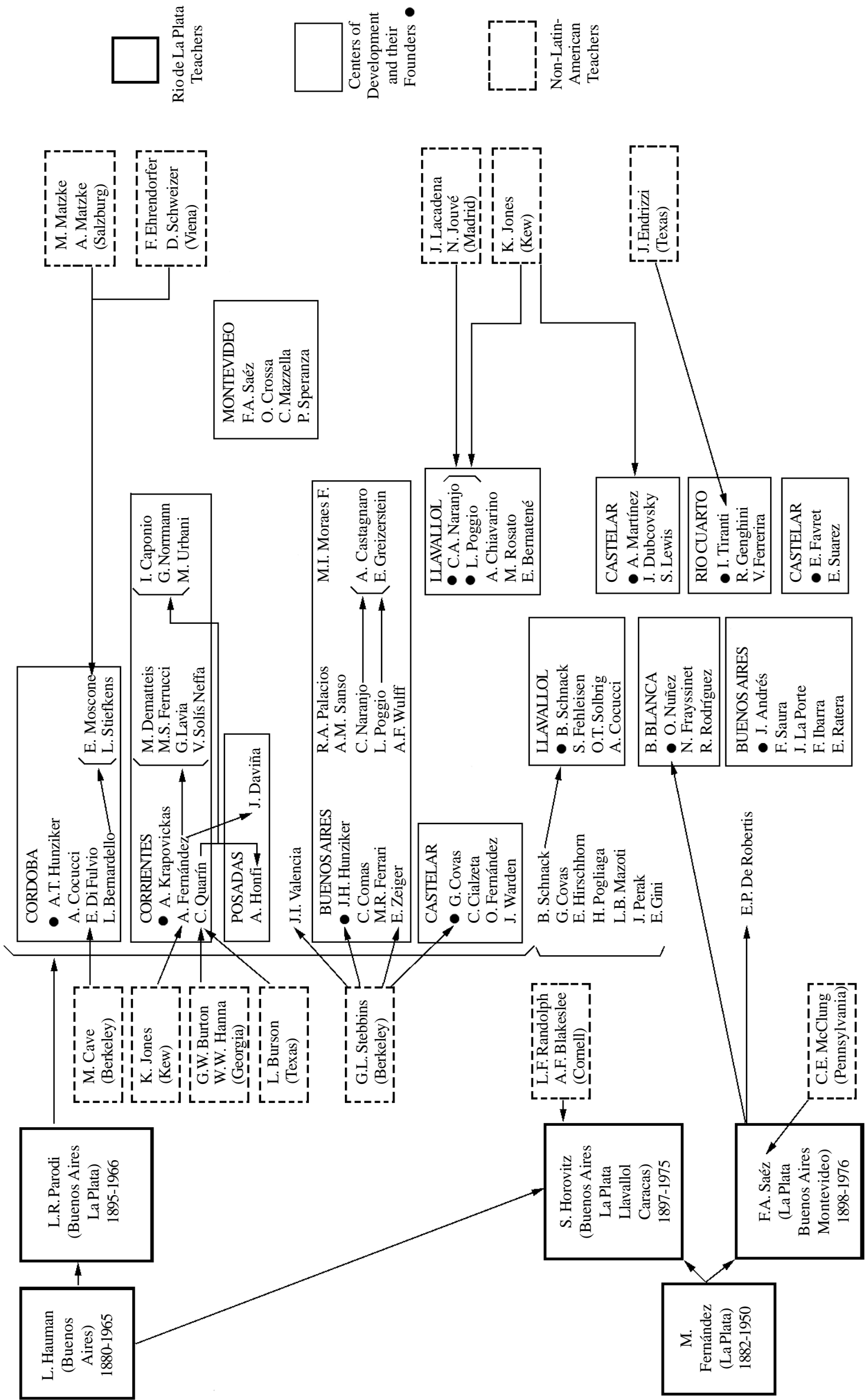

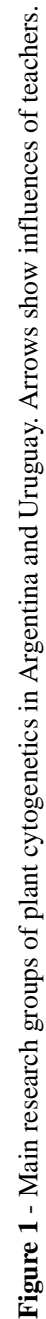


cytogenetics group in Buenos Aires, which disintegrated after the coup of 1966.

In the late forties, largely as an autodidact, Antonio Krapovickas started his cytotaxonomical research in Buenos Aires on more than 150 species of Malvaceae, which he continued in Córdoba, Tucumán and finally Corrientes. Here, he and his wife Carmen Cristóbal have been responsible for the creation of a botanical institute, where many cytologists have been trained, including Aveliano Fernández (working on Arachis and Turneraceae), Camilo Quarín and Guillermo Norrmann (Paspalum and Andropogon), Silvia Ferrucci (Sapindaceae) and Viviana SolísNeffa (Turneracae), among others.

Ovidio Núñez at La Plata, a student of Sáez and Parodi, studied the somatic chromosomes of 45 species of Paniceae (Gramineae) and made chromosome counts on several genera of grasses, published by L.R. Parodi in Gramineas Bonarienses (1946, 1958). Later with his students at Bahía Blanca he studied the evolution of species of Nothoscordum, a genus that also received the attention of Orfeo Crossa in Montevideo.

In the mid fifties and sixties Alfredo Cocucci and Emil Di Fulvio in Córdoba, working mainly on plant embryology, started chromosomal studies on several groups, the former in Orchidaceae and the latter (after training with Marion Cave, Berkeley) worked mainly on Liliaceae and Solanaceae and helped to train other cytologists like Luis Bernardello, who studied different families and likewise trained several cytologists, including Eduardo Moscone, who had further training with Friedrich Ehrendorfer and Dieter Schweizer in Vienna, as well as with Marjorie and Antonius Matzke in Salzburg, where he focused on Capsicum and Nicotiana tabacum chromosomes.

In my laboratory in Buenos Aires several cytologists were trained who did work on Gramineae, Compositae, Alstroemeriaceae, Zygophyllaceae, etc. (Figure 1) (Hunziker, 1994). Maria Irene B. Moraes Fernandes from Porto Alegre spent a couple of months in Buenos Aires working on the cytology of Paspalum, and when she returned to Porto Alegre she helped to develop a group of plant cytologists and evolutionists under the leadership of Prof. Helga Winge.

Carlos Naranjo and Lidia Poggio worked in Buenos Aires on the Amaryllidaceae, Larrea, Bulnesia, Bromus, Amaranthus, Glandularia, etc. and later worked at Kew with Keith Jones and at Madrid with Juan Lacadena and Nicolás Jouvé. In recent years they have continued their work on corn in Llavallol and Buenos Aires, training several students. Both of them and several other people that are not mentioned here but are listed in Figure 1 will report their results and advances in the present symposium.

Another cytogenetics group was established by Arturo Martinez, a student of K. Jones, in Castelar in the eighties, dealing with the cytogenetics of Oxalis, Gramineae, etc.

We may ask what factors hampered the development of cytogenetics in the area. The interference of politics at the universities produced intolerance, intrigues and discrimination greatly by disturbing academic and research activities. These problems plus low salaries, the lack of financial support for research and the various military dictatorships had serious negative effects on the development of science in Argentina and other Latin American countries. Moreover, the lack of vision of our statesmen that so far have ignored the fact that in the present world "knowledge is power" and have not given enough impulse and stimulus to the development of educational and scientific activities (Hunziker, 1990). As a consequence, in the second half of this century many cytologists in Argentina lost or left their positions and some were forced to emigrate to other countries. In 1947, S. Horovitz move to Venezuela and F.A. Sáez and Eduardo De Robertis to Uruguay, while in 1952, Otto Solbrig was expelled as a student from the University of $\mathrm{La}$ Plata and had to emigrate to the USA to finish his studies. In 1966, J.I. Valencia and many others left the country after the Onganía military coup and in 1976, O. Núñez and I. Tiranti lost their positions as professors at the Universidad del Sur (Bahía Blanca) because of political discrimination. But if history, as the great Cervantes has noted, can be "a warning about the future", we should strive everyday to maintain a democratic government and try to minimize the political struggles within the university and their resulting interference with academic activities and also try to foster a wide tolerance for the diverse opinions and positions of all intellectual activity, as is customary in many advanced countries. Furthermore, we should follow the example of Switzerland, for instance, where as stated by Aebi (1978) "the autonomy of the university is still intact, and the initiative and creativity of the individual scientist are not hampered by an exaggerated bureaucracy or by pseudodemocratic rules enforced by the least experienced and the least qualified".

\section{PERSPECTIVES}

It is difficult to make predictions about the future of plant cytogenetics. About a decade ago, for instance, we did not know about genomic in situ hybridization (GISH) or the fact that auto- and allopolyploids frequently have a multiple origin, that is, at different localities and with different parental genotypes (Soltis and Soltis, 1990). Undoubtedly cytogenetics in the near future, with the aid of molecular tools, will become more thorough and make rapid advances.

I would finally like to make a suggestion to all those who do not have at their disposal the means and funds required for the new and more expensive methodologies. With the rich plant biodiversity of Latin America, where there are taxonomic families and genera with unknown chromosome numbers, it is possible to find novelties using even inexpensive techniques.

\section{ACKNOWLEDGMENTS}

I heartily thank Professor Marcelo Guerra and the Organiz- 
ing Committee of the 1st Latin American Symposium on Plant Cytogenetics and Evolution for their invitation, their hospitality and their kindness towards me. Ing. Agr. A. Krapovickas, Dr. E. Moscone, Dr. C. Naranjo and Dr. O. Núñez and Dr. A. Sanso provided information or made valuable suggestions. Mrs. F. Ihasz diagramed Figure 1 and Mr. Alexander Hunziker corrected the English version.

\section{RESUMO}

Uma breve narrativa é dada sobre a origem e desenvolvimento de citogenética em plantas na Argentina e Uruguai, juntamente com alguns fatores que prejudicaram o desenvolvimento desta area.

\section{REFERENCES}

Aebi, H.E. (1978). Research. In: Modern Switzerland (Luck, J.M., ed.). The Society for the Promotion of Science and Scholarship, Inc., Palo Alto, California, pp. 129-156.
Hunziker, J.H. (1976). Francisco Alberto Sáez y su contribución al desarrollo de la citogenética rioplatense. Mendeliana 1: 69-74.

Hunziker, J.H. (1980). Bosquejo histórico y estado actual de la Genética en la República Argentina. An. Acad. Nac. Cienc. Exatas, Fís. Nat. B. Aires 32: 147-163.

Hunziker, J.H. (1990). Decadencia de Nuestro Sistema Científico-Tecno-

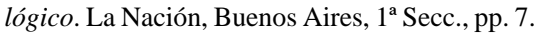

Hunziker, J.H. (1994). Origen y Desarrollo del Laboratorio de Genética Evolutiva de la Facultad de Ciencias Exactas y Naturales de la Universidad de Buenos Aires. Mendeliana 11 (Suppl.): 90-92.

Hunziker, J.H. and Sáez, F.A. (1976). Citogenética y Genética Evolutiva Vegetal y Animal en la Argentina. Historia y Bibliografía (1923-1972). Bol. Acad. Nac. Cienc. 51:284-323.

Mazoti, L. and Hunziker, J.H. (1976). Los precursores e iniciadores de la Genética en la Argentina. In: Evolución de las Ciencias en la República Argentina (1923-1972). Tomo 4: Genética (Mazoti, L.B. and Hunziker, J.H., eds.). Sociedad Científica Argentina, Buenos Aires, pp. 5-12.

Soltis, D.E. and Soltis, P.S. (1990). Chloroplast DNA and nuclear rDNA variation: Insights into autopolyploid and allopolyploid evolution. In: Biological Approaches and Evolutionary Trends in Plants (Kawano, S., ed.). Academic Press, London, pp. 97-117. 